\title{
Demographic potential in functional areas of the selected medium-sized cities in Poland and the Czech Republic
}

\author{
Marek Obrębalski ${ }^{1 *}$ \\ ${ }^{1}$ Department of Regional Economy, Faculty of Economics, Management and Tourism, \\ Wrocław University of Economics, Wrocław, Poland \\ *marek.obrebalski@ue.wroc.pl
}

\begin{abstract}
The article presents the population problem of urban functional area around selected medium-sized cities in Poland and the Czech Republic. Research work refers to six cities (on the Polish side - Jelenia Góra, Legnica and Wałbrzych - located in Lower Silesia region; on the Czech side - Hradec Králové, Liberec and Ústí nad Labem). These core cities with suburban areas co-create the functional urban areas with varied demographic structure and deve-lopment dynamics. In the analysed period, the population growth was observed only in Liberec. The largest total population among studied areas refers also to Liberec functional urban area. The population in suburban areas of the examined Polish and Czech cities is relatively younger than in the core cities. Functional approach for development of urban areas founding depart from perception of demographic problem and challenges only by prism of administrative borders becomes more important.
\end{abstract}

Key words: integrated territorial approach, ESPON, population, suburbanisation, Urban Audit, urban functional area, delimitation, urban development.

\section{Highlights for public administration, management and planning:}

- Factors influencing demographic future of urban areas are studied and concerns are raised as a result of the decline in residents' number and of the gradual deterioration of population age structure.

- The aging of local communities is particularly visible in core cities, whereas the population in suburban areas of the examined cities is younger.

Received: 12 Apr 2017 - Received in revised form 31 May 2017 - Accepted: 8 Jun 2017

\section{Introduction}

Functional approach to the development of urban areas, which assumes moving away from the perception of problems and challenges, through the perspective of administrative borders only, has been gaining an increasing importance (Obrębalski 2013, p. 150). The regulations of European cohesion policy, covering the period 2014-2020, also put emphasis on the place-based policy. The growing significance of functional approach towards the development of urban areas also results in the clearly higher interest in the problems of functional urban areas development, including the demographic one.
The research conducted in this area requires the availability of adequate information, covering cities and their functional milieu, in order to carry out both domestic and international analyses. The European Commission, among other institutions, already in June 1997, paid attention to these issues and together with Eurostat initiated the implementation of the Urban Audit programme. So far six editions of this programme have been carried out, where one of the research purposes is to take into account not only cities within their administrative borders, but also (if possible) the entire agglomerations. 
The purpose of the presented study is to identify and assess changes of the demographic potential in the group of several Polish and Czech middlesized cities and the related functional areas. The spatial scope of the research covers: on the Polish side - Jelenia Góra, Legnica and Wałbrzych, whereas on the Czech side - Hradec Králové, Liberec and Ústí nad Labem. These cities represent core centres, primarily for their closer milieu and along with them co-create functional urban areas characterized by a diversified demographic structure and a developmental dynamics. Jelenia Góra and Ústí nad Labem were covered by the
Urban Audit programme starting from its second edition in 2003, whereas the other cities were included in this programme starting from the next edition in 2006, in which the statistical data were collected for 2004. Therefore, the time range of the study covers the years 2004-2013 (base year of the latest Urban Audit edition).

\section{Demographic potential of cities}

The demographic potential of cities and its structure changes have a significant impact on the course of socio-economic processes.

Table 1 - Changes of population number in the analysed Polish and Czech cities in the years 2004-2013 (source: own elaboration based on Eurostat data).

\begin{tabular}{|c|c|c|c|c|}
\hline Cities & 2004 & 2008 & 2013 & Index of changes $(2004=100)$ \\
\hline Ústí nad Labem & 93859 & 95289 & 93523 & 99.64 \\
\hline Liberec & 97400 & 100914 & 102301 & 105.03 \\
\hline Hradec Králové & 94694 & 94497 & 92904 & 98.11 \\
\hline Jelenia Góra & 87643 & 85378 & 81985 & 93.54 \\
\hline Wałbrzych & 127566 & 122411 & 117926 & 92.44 \\
\hline Legnica & 106143 & 104489 & 101992 & 96.09 \\
\hline
\end{tabular}

Table 2 - Changes of number and share of population aged over 75 in the analysed Polish and Czech cities in the years 2004-2013 (source: own elaboration based on Eurostat data).

\begin{tabular}{lrrrrrr} 
& \multicolumn{2}{c}{$\mathbf{2 0 0 4}$} & \multicolumn{3}{c}{$\mathbf{2 0 1 3}$} \\
\cline { 2 - 7 } Cities & population & share in \% & population & share in \% & population & share in \% \\
\hline Ústí nad Labem & 5325 & 5.67 & 5633 & 5.91 & 5929 & 6.34 \\
Liberec & 6188 & 6.35 & 6668 & 6.61 & 6839 & 6.69 \\
Hradec Králové & 6834 & 7.22 & 7860 & 8.32 & 8426 & 9.07 \\
Jelenia Góra & 5543 & 6.32 & 6542 & 7.66 & 7066 & 8.62 \\
Wałbrzych & 7342 & 5.76 & 8778 & 7.17 & 9904 & 8.40 \\
Legnica & 5132 & 4.83 & 6011 & 5.75 & 6839 & 6.71
\end{tabular}

They e.g. stimulate the extent of the needs in terms of social infrastructure, the level of occupational activity, as well as co-decide about the dynamics of a particular city future development.

Population size of the analysed Lower Silesian cities and those in northern Czech Republic is diversified and in 2013 was ranging from almost 118000 people in Wałbrzych to nearly 82000 residents in Jelenia Góra. The population of these medium-sized cities was characterised, in the period 2004-2013, by the diversified tendencies of changes in terms of their dynamics and direction. This problem is illustrated in Table 1.

The increase in population number was recorded in the analysed period only in Liberec, where the population size increased by over $5 \%$ in the years 2004-2013. Moreover, it should be emphasized that, by far, the lowest decline of population was observed in the other analysed Czech cities (Ústí nad Labem - by only slightly less than $0,4 \%$ and 
Hradec Králové - by 1,9). The significant drop in population was, however, recorded in Wałbrzych (by almost 7,6\%), in Jelenia Góra (by nearly 6,5\%) and in Legnica (by 3,9\%). It should, however, be indicated that in accordance with the demographic forecasts till 2020 the general decline in population number will become visible, even though its level will not remain even.

Population structure changes by age are particularrly important for both social and economic reasons. The studied cities reveal the clear process of local communities aging.

For example, a continuous increase in the number and share of population aged over 75 is registered, what is presented in Table 2 .

The aging of the studied urban communities resuIts from the growing share of population aged 75 and over. The significantly highest share of this population group refers to Hradec Králové (over 9\%), Jelenia Góra (over 8,6\%) and Wałbrzych $(8,4 \%)$, whereas the relatively lowest - Ústí nad Labem (only 6,3\%).

The advancing population aging in particular cities has direct impact on the functioning of local job markets, the demand scale on public services, e.g. related to education and upbringing, health care and social aid, the scope and size of investment projects, as well as the broadly approached economics of these cities.

\section{The processes of functional and spatial integration and suburbanization}

The characteristics of a modern city, rights of its existence and development cannot be analysed in isolation from its closer and more distant milieu, since these components exert mutual, ongoing and multifaceted impacts and are subject to continuous integration processes.

The integration processes consist predominantly in the development of the network of reciprocal various relationships between the individual territorial units. They result in the creation of a new entity made up of these parts. In this perspective a city and its milieu (especially the closer one) represent a single, cooperating social, economic and spatial system, whereas an approach to a city as an individual entity functioning in separation from its milieu seems pointless.

The spatially extensive urbanization processes and polarization oriented city impacts, not just of the large ones, have a particular place in modern processes of territorial development. In accordance with the classical polarization theory by F. Perroux a city plays the role of a growth pole having a multifaceted influence on its milieu (see e.g. Korenik, Zakrzewska-Półtorak, 2011, p. 39). The polarization power of such centre is not only related to population concentration, but also to the structure and the specific nature ingrained in the production and services provision potential, whereas the milieu ability to become influenced by polarization forces (polarization impulses absor-ption) is determined by e.g. communication availability, urbanization level and the configuration of economic structure.

The research covering the demographic development of cities and their multifaceted relationships with the milieu allow presenting several subsequent phases. They illustrate - in L. Klaassen's opinion - the particular city development (life) cycle made up of the following phases:

- urbanization (or concentration) - when the core (central) area is developing faster than its milieu;

- suburbanization (or deconcentration) - when the overall core area (centre) development presents a slower pace and, in time, the growth in population number and economic activity occurs in its peripheral zone;

- de-urbanization (or dispersion) - when a city or its suburban zone are characterized by stagnation or develop slower than the core centres, located in the zone of more distant milieu;

- re-urbanisation - when the deconcentration process is stopped and the redevelopment of core (central) areas occurs, e.g. as a result of their revitalisation.

The problem of suburbanization should be analysed from many perspectives, taking into account its e.g. demographic, spatial management or economic aspects.

The symptoms of suburbanization, in terms of demographics, are manifested by the continuous 
migrations of population and its dwelling in suburban areas. In this respects the reasons underlying suburbanization take the form of factors which attract residents to suburban areas or "push" them out of cities, also due to social, ecological, cultural, psychological, etc. factors.

The spatial aspect of suburbanization is, in turn, connected not only with the development of residential housing in a suburban zone, but also with shaping its urban development forms and management. An increased construction activity, manifestted by e.g. the growing number of residential housing provided for use in suburban areas remains, apart from population migration, the significant measure of suburbanization processes advancement.

In an economic sense, suburbanization is manifestted by the development of non-agricultural (as well as modern) economic activities in suburban areas. Its symptoms also take the form of commuting to work. Along with that they become one of the factors responsible for the advancing semi-urbanization of rural areas. Rural residents commuting every day to work to an urban centre and using urban infrastructure also, to a great extent, fulfil many of their other social needs. They represent the category of functionally urban and occupationally urbanized population.

The presented multifaceted suburbanization indicates the possibility of approaching it in a threefold manner (Lisowski \& Grochowski 2009), i.e. as:

- urbanization of the suburban zone - the expansion of city attributes;

- city expansion - population movement (jobs and services) to the suburban zone;

- the stage of agglomeration development (functional urban area) - the process of functional relations network development between the core city and its milieu accompanied by the mutual multiband impacts.

Therefore, modern suburbanization, the essence of which takes the form of urban settlement dispersion process, turns out to be not just a social, spatial and organizational problem, but also - and to a much larger extent - an economic one. The issues of suburban, occasionally very strong, burdens affecting many cities become widely recognized. They are manifested by e.g. "outflow" of budget revenues, along with the simultaneous taking advantage of urban infrastructure by the population settling in the suburban zone. Practically, however, this situation is characteristic for the vast majority of middle-sized and large cities, not just Polish or Czech ones.

\section{Functional urban areas - the essence, delimitation problems, population}

A functional urban area represents the settlement system which is spatially continuous and made up of many separate administrative territorial units. Therefore, it covers the centre (the main city - the core) and the surrounding, functionally and spatially linked external zone. Functional urban areas are characterized by a significant power of internal relationships occurring between the central city and its functional milieu, primarily manifested by the intensity of commuting to work, high scale flow of different type of goods and services, mutual relationships between the job and residential markets, supra-local range of particular technical infrastructure subsystems' operation and the consistency of spatial management structures and natural environment (Obrębalski 2016, p. 139).

The detailed delimitation of territorial borders of functional urban areas results in many practical problems, starting from the identification of urban development and specification of local communities' size and structure, through determining the nature of area spatial management or the intensity and type of relationships between the central city and the other territorial units. The problems of criteria and methods selection, as well as the measurement of delimitation characteristics do not, however, undermine the significant importance of spatial integration processes and their effects in the form of complex settlement systems. 
Table 3 - Population of functional areas of the analysed Polish and Czech cities by ESPON in 2002 (in thous.) (source: own elaboration based on: Study on Urban Functions, ESPON project 1.4.3. - Final Report, ESPON Monitoring Committee, Luxembourg, March 2007, pp. 37-38 i 95).

\begin{tabular}{|c|c|c|c|c|}
\hline \multirow[t]{2}{*}{ Specification } & \multirow{2}{*}{$\begin{array}{l}\text { Regional functional urban } \\
\text { areas (RFUA) }\end{array}$} & \multicolumn{2}{|l|}{ Core-city } & \multirow{2}{*}{$\begin{array}{l}\text { Settlement } \\
\text { units of core- } \\
\text { city milieu }\end{array}$} \\
\hline & & $\begin{array}{l}\text { population } \\
\text { number }\end{array}$ & share of RFUA in \% & \\
\hline Ústí nad Labem & 118 & 101 & 85.59 & 17 \\
\hline Liberec & 247 & 101 & 40.89 & 146 \\
\hline Hradec Králové & 161 & 97 & 60.25 & 64 \\
\hline Jelenia Góra & 131 & 92 & 70.23 & 39 \\
\hline Wałbrzych & 248 & 176 & 70.97 & 72 \\
\hline Legnica & 125 & 109 & 87.20 & 16 \\
\hline
\end{tabular}

In this context one of the European Commission research programmes should be indicated, which has been implemented by the European Observation Network for Territorial Development and Cohesion (ESPON). Within its framework the problem of delimitation and typology of functional urban areas in Europe was analysed. For this purpose Functional Urban Areas (FUA) were adopted as the basic unit. The conducted research took into account the ranks of particular cities in terms of their population number, the role of transport, tourism, industry, the sphere of science and managerial functions. Unfortunately, in many cases, due to the absence of adequate statistical information the important functional relationships were not included (e.g. in terms of commuting to work). As a result of the applied criteria 28 regional functional urban areas (RFUA) were identified, among others, in the area of Poland as linked with middle-sized cities, e.g. Legnica, Jelenia Góra and Wałbrzych (Study on Urban Functions 2007, p. 95). In the area of the Czech Republic, in turn, 14 such areas linked e.g. with Ústí nad Labem, Liberec and Hradec Králové were distinguished Králové (Study on Urban Functions 2007, pp. 37-38).

The largest functional urban areas (by ESPON), in terms of population number, are related to Wałbrzych and Liberec. Both of these agglomerations had almost 250000 residents according to the data from 2002. The relatively smallest ones, in turn, were the functional urban areas of Ústí nad Labem, Legnica and Jelenia Góra. The level of population potential concentration was, at the same time, diversified in core cities (centres). The highest level was identified in Legnica which, in the analysed period of time, was inhibited by over $87 \%$ of total Legnica functional urban area population and Ústí nad Labem (almost $85,6 \%$ of this RFUA population). The definitely lowest level of population concentration comparing to the entire functional urban area was recorded in case of Liberec (only almost $41 \%$ resides in Liberec and the remaining over $59 \%$ in settlement units of its milieu).

An interesting approach to delimitation and various aspects of functional urban areas has been presented for years by the European public statistics. Within the framework of Urban Audit programme, representing the joint initiative of the European Commission and Eurostat, the development of urban areas is being monitored in several dimensions. The information is collected for three spatial levels:

- Core City-C;

- Larger Urban Zones - LUZ as the areas of urban centres impact;

- Sub-city Districts - SCD. 
Table 4 - Population of functional areas of the analysed Polish and Czech cities by Urban Audit in 2013 (source: own elaboration based on Eurostat data).

\begin{tabular}{|c|c|c|c|c|}
\hline \multirow[t]{2}{*}{ Specification } & \multirow{2}{*}{$\begin{array}{l}\text { Larger Urban Zones } \\
\text { (LUZ) }\end{array}$} & \multicolumn{2}{|l|}{ Core city } & \multirow{2}{*}{$\begin{array}{l}\text { Settlement units of } \\
\text { core-city milieu }\end{array}$} \\
\hline & & population & $\begin{array}{l}\text { share of LUZ } \\
\text { in } \%\end{array}$ & \\
\hline Ústí nad Labem & 248315 & 93523 & 37.66 & 154792 \\
\hline Liberec & 261413 & 102301 & 39.13 & 159112 \\
\hline Hradec Králové & 162651 & 92904 & 57.12 & 69747 \\
\hline Jelenia Góra & 138231 & 81985 & 59.31 & 56246 \\
\hline Wałbrzych & 175760 & 117926 & 67.09 & 57834 \\
\hline Legnica & 133288 & 101992 & 76.52 & 31296 \\
\hline
\end{tabular}

Larger urban zones (LUZ) are, in this respect, defined as one or several surrounding the core city rings of territorial units at LAU1 level (counties) and LAU2 level (communes), of which at least $15 \%$ population commutes to work to this core city.

Differentiation of the population location in the studied larger urban zones around the medium sized core-cities in structural terms is presented in Table 4.

The research conducted by Eurostat, within the framework of Urban Audit programme, indicates, on the other hand, that the largest, in terms of population, the so-called larger urban zone is linked with Liberec (261 400 residents) and Ústí nad Labem (248 300 people). The relatively smallest population refers to the urban zones of Legnica (only 133300 residents) and Jelenia Góra (138 200 residents).
As far as the population concentration level in the so-called larger urban zones of the analysed centres is concerned, it should be indicated that the highest one refers to Legnica, which is inhabited by over $76,5 \%$ of the total Legnica LUZ population and Wałbrzych (over $67 \%$ population of this LUZ). The definitely lowest level of demographic potential concentration refers to Ústí nad Labem (only almost $37.7 \%$ of total LUZ population lives in this centre, whereas the remaining $63 \%$ in the settlement units of its milieu) and Liberec (the concentration slightly over $39 \%$ of the entire LUZ population).

The interesting information, especially comparing to the data presented in Table 2 , refer to the aging process advancement, characteristic for the communities residing in the settlement units of the analysed urban zones, apart from the core cities. This problem is illustrated in Table 5.

Table 5 - Number and share of population aged 75 and more in core-cities and in settlement units of its milieu in the analysed LUZ in 2013 (source: own elaboration based on Eurostat data).

\begin{tabular}{|c|c|c|c|c|}
\hline \multirow[t]{2}{*}{ Specification } & \multicolumn{2}{|l|}{ Core city } & \multicolumn{2}{|c|}{ Settlement units of milieu } \\
\hline & population & share in $\%$ & population & share in \% \\
\hline Ústí nad Labem & 5929 & 6.34 & 8364 & 5.40 \\
\hline Liberec & 6839 & 6.69 & 9589 & 6.03 \\
\hline Hradec Králové & 8426 & 9.07 & 4564 & 6.54 \\
\hline Jelenia Góra & 7066 & 8.62 & 3448 & 6.13 \\
\hline Wałbrzych & 9904 & 8.40 & 4710 & 8.14 \\
\hline Legnica & 6839 & 6.71 & 1872 & 5.98 \\
\hline
\end{tabular}


The data presented in Table 5 allow concluding that the relatively younger population resides in the suburban zones of the studies Polish and Czech middle-sized cities. The percentage of population aged 75 and more in the milieu settlement units is significantly lower than in case of the individual, analysed core cities. For example, the larger urban zone of Jelenia Góra these shares present the following levels: $8,62 \%$ in Jelenia Góra and $6,13 \%$ in the territorial units of its milieu. It probably results from the inflow of the relatively young people to suburban zones, which stimulates positive age structure changes. A conclusion can even be drawn that the areas subject to suburbanization processes are characterized by the same slower pace of the population aging process.

\section{New presentation of a city and a functional urban area in the European statistics}

For the purposes of methodologically consistent comparative studies and analyses, not only in national scales, but primarily in the European one, in 2011 the European Commission, in cooperation with $\mathrm{OECD}$, suggested the new, uniform definitions of e.g. a city and functional urban zones (Methodological Manual, July 2016, p. 10-11). Furthermore, it was specified that the European urban statistics shall take into account, in the conducted research, the following spatial levels (Urban Europe 2016, p. 26):

- Functional Urban Area - FUA;

- Greater City - before the "kernel";

- City - before the "core city";

- Sub-City Districts level 1;

- Sub-City Districts level 2.

The delimiting and defining procedures, covering the above listed levels of territorial units (including a city) is initiated by placing them on the grid space creating uniform cells (areas) in terms of size ( $1 \mathrm{~km}^{2}$ in area).

The statistical definition of a city was formed as a result of applying the four level procedure:
1. the areas (grid cells) with the population density higher than 1500 residents per km2 are identified;

2. the adjacent grid cells are combined into clusters, which having the population of minimum 50000 residents are defined as an "urban centre";

3. all localities (communes) with at least half of their population residing in the area of such urban centre are indicated as the potential parts of a city;

4. A city is defined as a territorial unit meeting the following criteria:

- it is an element of the administrative structure;

- at least $50 \%$ of the city population resides in the area of an urban centre;

- at least $75 \%$ of an urban centre population lives in a city.

In the light of this delimitation procedure a city represents a local administrative unit (LAU) linked with an "urban centre" which population number is at least 50000 and made up of a cluster of the adjacent areas (grid cells of $1 \mathrm{~km}^{2}$ in area) with the population density of at least 1500 residents per $\mathrm{km}^{2}$.

Based on this definition, more than 800 cities, with urban centres having at least 50000 residents, were identified in the European Union Member States, Switzerland, Iceland and Norway.

The term Greater City is, in turn, applied in cases when an urban centre is spatially spread far beyond the administrative borders. It mainly refers to large cities characterized by the developed metropolitan functions.

The sub-city districts (SCD1 and SCD2) are delimited based on the criterion of population size in the capital cities of particular countries and in the cities with the population over 250000 These units cover the areas inhabited by minimum 5000 and maximum 40000 people. In practice they represent districts of these cities (SCD1) or the units delimited based on the demographic criteria (SCD2). 
In turn, the functional urban area covers a city along with the commuting zone, within the boundaries of which there are communes from which at least $15 \%$ residents commute to the city to work. Such communes also have to present a spatially continuous area.

The described methodological approach to the problems of more or less complex urban settlement units' identification results in a different than the existing so far identification of the urbanization level (Dijkstra \& Poelman 2014, pp. 5-10). Based on the population density criterion of the local administrative units (LAUs) the following are distinguished (Urban Europe 2016, pp. 24-26):

- urban areas - defined as the sum or the city average and towns with suburbs;

- cities (densely populated areas) - at least $50 \%$ of population resides in "urban centres", i.e. in the areas featuring population density of at least 150 residents per $\mathrm{km}^{2}$ and population number of at least 50 000;

- towns and suburbs (areas presenting average population density) - at least $50 \%$ of population resides in "urban clusters", i.e. in the areas not defined as cities; an urban cluster is defined as a set of neighbouring cells (units of $1 \mathrm{~km}^{2}$ in area), which population density amounts to at least 300 residents per $\mathrm{km}^{2}$ and the population of minimum 5000 inhabitants;

- rural areas (sparsely populated areas) - at least $50 \%$ of population lives in rural grid cells.

Practical identification of urbanization level based on population density grids requires the integration of geoinformation systems and population registers.

The introduction of identical rules for identifying urban areas and determining the urbanization level based on the uniform population density grid cells in all European Union Member States would allow eliminating the currently existing methodological diversification in this respect and ensure information comparability in the European scale ${ }^{1}$.

Proper approach to the problems of city development measurement and assessment and functi- onal urban areas requires broad access to an extensive, in its scope, resource of diversified and comparable information. Any gaps in this matter limit and sometimes even make conducting complex and unbiased analyses and evaluations impossible. Therefore, it is needed to meet many contemporary challenges and predominantly to: simplify and unify the methodology of statistical research, improve data quality and availability and systematically implement the new, unified definitions of a city and functional urban areas.

In the past the quality of statistics was identified with its accuracy. Currently an agreed opinion is shared that quality has definitely much broader and multidimensional range. The features characterizing statistical information quality include usefulness, accuracy, timeliness, availability, interpretability, comparability, consistency and also completeness. Therefore, appropriate attention should be paid to providing the required quality of this information and taken into account in the process of the European statistics improvement, including the one referring to urban areas.

\section{Conclusions}

Population residing in a city and the related functional area has an extensive impact not only on the functioning of these territorial units, but also defines the directions and dynamics of their development. Moreover, population structure and characteristics decide, to an extent, about the perception of cities as attractive and competitive centres in the conditions of market competition.

Population structure changes of the analysed cities and functional urban areas, both Polish and Czech ones, presented diversified range, dynamics and directions. The clear effects of advancing suburbanization processes are well visible around the studied middle-sized cities. In almost all of these cities (apart from Liberec) population decline, caused by many factors of predominantly demographic, social and economic nature, was recorded. These factors shall also have impact on the demographic future of urban areas. In the context of demographic future the concerns are raised not only as a result of the 
observed decline in residents' number, which has been progressing for many years, but also the process of gradual deterioration of population age structure in the analysed cities and functional urban areas. The aging of local communities is particularly visible in core cities of the analysed functional urban areas.

In-depth demographic studies in an international dimension are hindered by the significant gaps in the availability of appropriate statistical information. The European public statistics is trying to face these challenges, especially in terms of definition oriented consistency, research methodology unification or bridging the extent of statistical gap in the available information about urban areas. Beyond any doubt, the effectiveness of the statistical observation system, covering cities and functional urban areas, is one of the basic conditions for an effective steering of territorial development in its various spatial scales. Having considered the need for the continuous functioning and development of each component, in a more or less complex territorial system, the problem of information base, in the context of decisions made by the public authorities and primarily by the local selfgovernment, remains of particular importance.

\section{Notes}

${ }^{1}$ For example, in the Czech Republic a city is a locality with at least 2000 population, whereas in Poland there are no binding population criteria in this matter and a city is defined as a settlement unit which was awarded city rights.

\section{References}

Dijkstra L, Poleman H (2014) A harmonised definition of cities and rural areas: the new degree of urbanization. Directorate-General for Regional and Urban Policy, European Commission.

Korenik S, Zakrzewska-Półtorak A (2011) Teorie rozwoju regionalnego - ujęcie dynamiczne. Uniwersytet Ekonomiczny, Wrocław.

Lisowski A, Grochowski M (2009) Procesy suburbanizacji. Uwarunkowania, formy i konsekwencje. Instytut Geografii SpołecznoEkonomicznej i Gospodarki Przestrzennej, Uniwersytet Warszawski, Warszawa.

Methodological Manual on City Statistics. 2016/2017 data collection (2016) Eurostat, European Union.

Obrębalski M (2013) Współczesne problemy krajowej i regionalnej polityki miejskiej. „Biblioteka Regionalisty” nr 13.

Obrębalski M (2016) Problemy delimitacji miejskiego obszaru funkcjonalnego - studium przypadku Jeleniej Góry. W: Gospodarka lokalna w teorii i praktyce. Red. R. Brol, A. Sztando, B. Bal-Domańska, Prace Naukowe UE we Wrocławiu nr 432, Uniwersytet Ekonomiczny, Wrocław 2016.

Study on Urban Functions, ESPON project 1.4.3. - Final Report (2007) ESPON Monitoring Committee, Luxembourg.

Urban Europe. Statistics on cities, towns and suburbs (2016) Publications Office of the European Union, Luxembourg. 